\title{
THE PIN-TAILED WHYDAH AS A BROOD PARASITE OF THE SCALY-BREASTED MUNIA IN SOUTHERN CALIFORNIA
}

\author{
JOHN F. GARRETT, 711 South Mentor Ave, Pasadena, California 91106; \\ curvirostra9@gmail.com \\ KIMBALL L. GARRETT, Natural History Museum of Los Angeles County, Los \\ Angeles, California 90007; kgarrett@nhm.org
}

ABSTRACT: Populations of the Pin-tailed Whydah (Vidua macroura), native to sub-Saharan Africa, have greatly increased in southern California in recent years, prompting speculation as to which species serve as hosts to this obligate brood parasite. Field studies and opportunistic sightings during the summer of 2014 strongly suggest that the Scaly-breasted Munia (Lonchura punctulata), an introduced species also derived from the pet trade, is the principal host species in the region. We present evidence for this based on investigation of munia nests by female whydahs and several instances of adult munias feeding recently fledged whydahs. This novel host-parasite relationship implies that any potential spread of the Pin-tailed Whydah in North America is at least partly dependent on the distribution of the Scaly-breasted Munia.

The Pin-tailed Whydah (Vidua macroura), a sub-Saharan African passerine of the family Viduidae, is an obligate brood parasite on finches of the family Estrildidae (Payne 2010a). In its native range, it preferentially parasitizes the Common Waxbill (Estrilda astrild). This closely co-evolved relationship includes mimicry of the pattern of the spotting on the inside of the mouths of nestling waxbills by nestling whydahs, in order to stimulate feeding by the foster parents (Mines 1999). In some regions of Africa with fewer Common Waxbills, Pin-tailed Whydahs utilize Swee Waxbills (Coccopygia melanotis), Bronze Mannikins (Spermestes cucullata), and other estrildids as hosts (Friedmann 1960, Mines 1999, Lansverk et al. 2015, Lowther 2016).

Since at least the 1990s, small numbers of Pin-tailed Whydahs have been noted in weedy river beds, parks, and flood-control basins on the coastal slope of southern California, particularly concentrated from La Mirada in southeastern Los Angeles County to the Santa Ana River in Orange County. Initially, because of the small numbers of whydahs and lack of traditional hosts, birders attributed sightings to recent escapees and not local breeding. More recently, however, the number of observations and the size of flocks have increased dramatically, raising the question of local breeding. For example, at least 83 individuals were foraging together at La Mirada Park on 31 October 2013 (M. C. Long, L. Garrett, and E. MacPherson; http:// ebird.org/ebird/view/checklist?subID=S15534115) and 75-100 were at the Fairhaven Momorial Park in northeast Santa Ana, Orange County, in the fall of 2013 (T. E. Wurster, fide D. R. Willick, pers. comm). Such observations included birds in juvenal and formative plumage, evidence that whydahs were breeding locally.

Urban regions of the coastal slope of southern California have seen an increasing suite of non-native passerines with breeding populations established from released or escaped birds imported for the pet trade (Johnston and Garrett 1994, Pranty and Garrett 2011). Among the most successful of these is the Scaly-breasted Munia (Lonchura punctulata punctulata) 
of the Indian subcontinent, now well-established over much of the region (Pike et al. 2014). While occasional escapees of known whydah hosts of the genera Estrilda and Amandava are detected in southern California, there are no known breeding populations of these potential hosts; for example, Bronze Mannikins are regularly noted in small numbers in urban southern California, and are suspected of but not yet documented as breeding. Therefore, we considered the most likely host to be the Scaly-breasted Munia, the only estrildid widely established in southern California. Furthermore, data at www.eBird.org revealed close range congruence between the current ranges of the Pin-tailed Whydah and Scaly-breasted Munia; the munia is found extensively from San Luis Obispo County to San Diego County, and the whydah shadows this distribution, particularly in Los Angeles and Orange counties. To investigate host-parasite relationships, J. F. Garrett sought breeding whydahs in southern California in 2014 by monitoring key areas from La Mirada in southeastern Los Angeles County to Tustin in central Orange County.

\section{METHODS}

We used www.eBird.org to identify sites of concentrations of Pin-tailed Whydahs in summer or fall. The main sites we visited were La Mirada Park and La Mirada Creek Park in La Mirada and Craig Regional Park in Fullerton, Orange County; J. F. Garrett visited each of these sites at least three times each week from 16 June to 19 September 2014 and made at least one visit to each of the following additional sites: in Orange County, Arovista Park in Brea, the Santa Ana River from Lincoln Avenue to Tustin Avenue in Orange, Yorba Regional Park in Anaheim, Mile Square Regional Park in Fountain Valley, Gilman Park in Fullerton, Huntington Central Park in Huntington Beach, and San Joaquin Marsh in Irvine; in Los Angeles County, Viña Vieja Park in Pasadena and the Whittier Narrows and the Rio Hondo in South El Monte. We further solicited observations from local birders of any evidence of breeding by Pin-tailed Whydahs in these or any nearby areas.

We followed female Pin-tailed Whydahs to see if they displayed any interest in the nests of other birds, and we also investigated nests of the Scaly-breasted Munia and any other estrildids for signs of whydah parasitism, although direct examination of nest contents was not possible. J. F. Garrett recorded additional observations on the Pin-tailed Whydah's natural history, including habitats, movements, and behavior.

We calculated range overlap between the Pin-tailed Whydah and Scalybreasted Munia in their core range in California by summing the number of ten-minute blocks in which each species has been recorded in eBird; we did not include in the tally outlying ten-minute blocks from which only a single individual had been reported.

\section{RESULTS}

Habitats

Male Pin-tailed Whydahs generally displayed in habitats similar to those used by nesting Scaly-breasted Munias: tall trees, often pines, an adjacent 


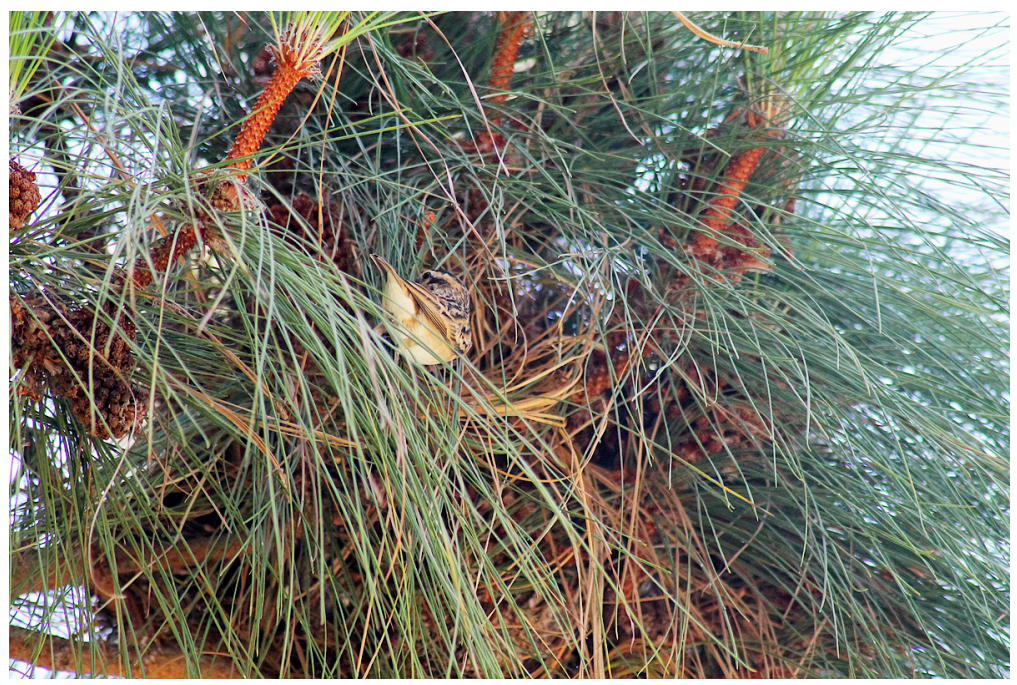

Figure 1. Female Pin-tailed Whydah at entrance to nest of the Scaly-breasted Munia in a pine tree at La Mirada Creek Park, Los Angeles County, California, 16 June 2014.

Photo by John F. Garrett

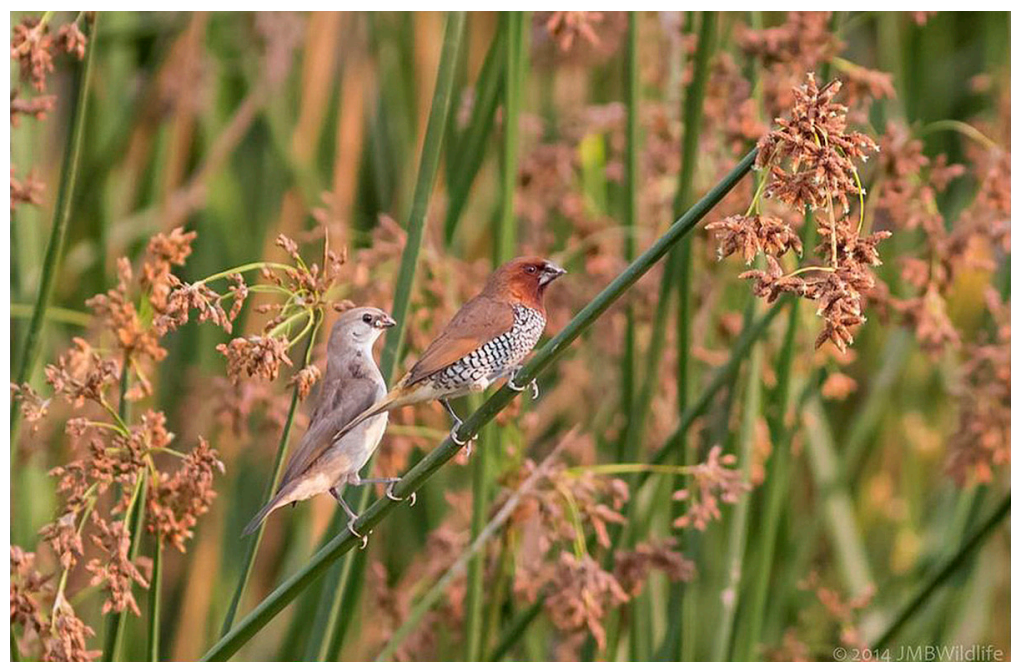

Figure 2. Fledgling Pin-tailed Whydah accompanying an adult Scaly-breasted Munia at San Joaquin Marsh in Irvine, Orange County, California, 29 July 2014.

Photo by Jeff Bray 


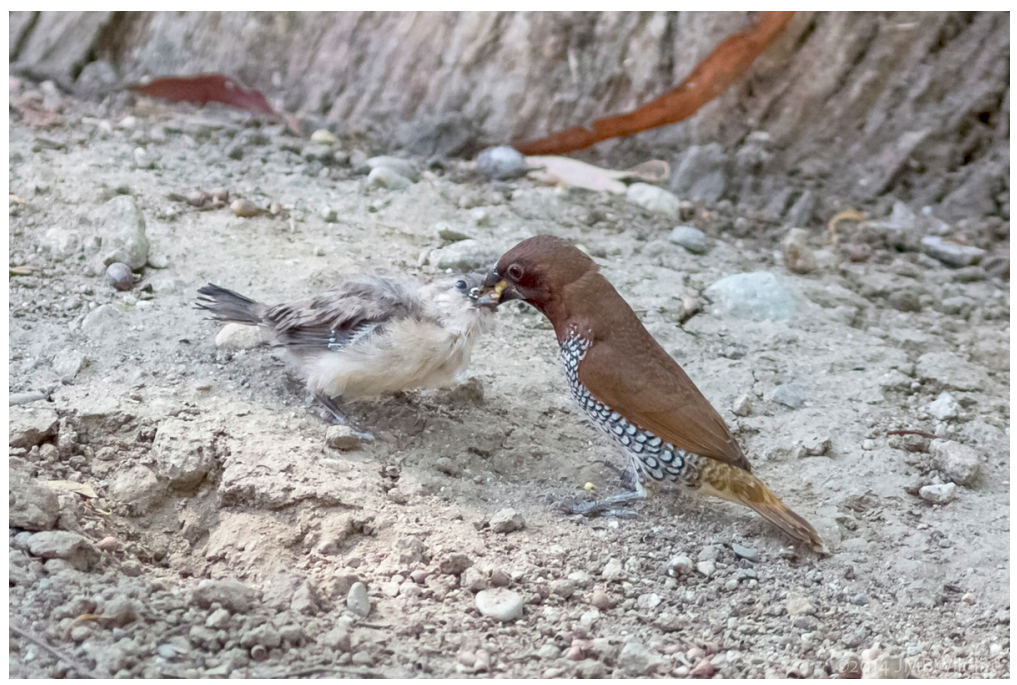

Figure 3. Fledgling Pin-tailed Whydah being fed by an adult Scaly-breasted Munia at Riverdale Park, Anaheim, Orange County, California, 6 September 2014.

Photo by Jeff Bray

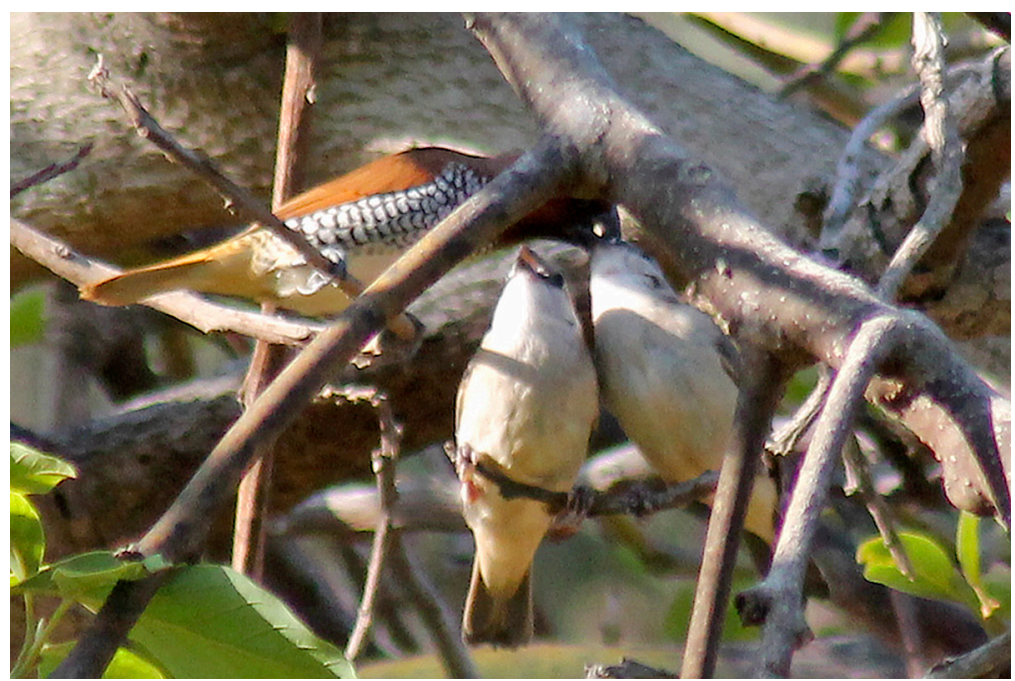

Figure 4. Scaly-breasted Munia feeding two fledged Pin-tailed Whydahs at La Mirada Creek Park, Los Angeles County, California, 11 August 2014.

Photo by John F. Garrett 


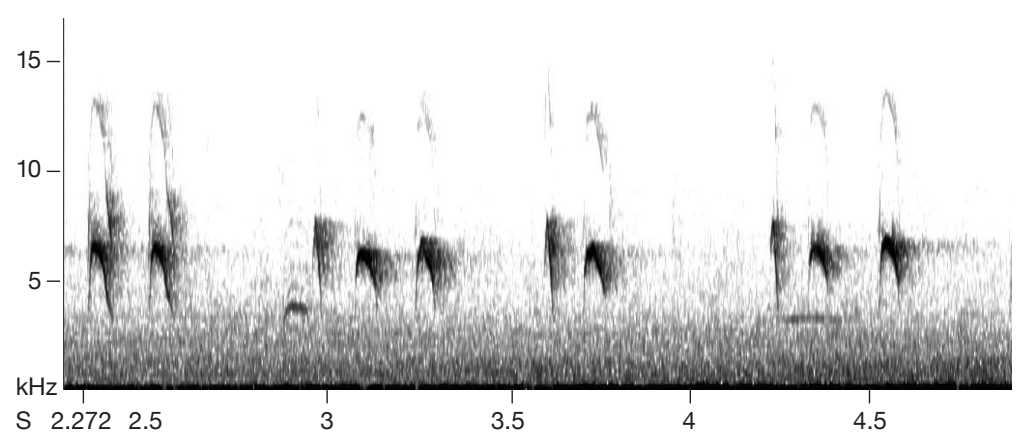

Figure 5. Begging call of a fledgling Pin-tailed Whydah, recorded by J. F. Garrett at La Mirada Creek Park, Los Angeles County, California, 28 August 2014.

expanse of open lawn, and at least a trickle of running water. Early in the breeding season, however, whydahs rarely foraged with other species. During this time, whydahs of various ages often behaved aggressively toward munias and other passerines such as the House Finch (Haemorhous mexicanus), often hovering in mid-air and darting repeatedly at targets. In late fall and winter, whydahs often formed large single-species flocks on lawns or along watercourses but sometimes joined other granivorous passerines, particularly Chipping Sparrows (Spizella passerina).

Of 40-45 Scaly-breasted Munia nests discovered, it was unclear how many were active, as many were built but subsequently unused. Most nests were 6-25 m high in planted Pinus spp., although a few were built in Liquidambar styraciflua or Jacaranda mimosifolia. Paralleling the habitats where male whydahs displayed, all nests were located near large lawns, usually near some weedy watercourse that the birds used for foraging and collecting nest material. Because of their height above ground none of the nests we found was accessible for direct examination of eggs or young.

\section{Breeding}

Several times early in the munias' summer/fall breeding season J. F. Garrett observed a female Pin-tailed Whydah closely investigating munia nests (Figure 1). Although no whydahs were observed to enter an active nest or deposit an egg, he observed a female entering an abandoned munia nest on 16 June and 19 September 2014.

The first confirmation of the Pin-tailed Whydah using the Scaly-breasted Munia as a host came from the San Joaquin Marsh, where Jeff Bray photographed a juvenile whydah following and being fed by adult munias on 29 July 2014 (Figure 2). Bray obtained numerous photos of another munia feeding a very recently fledged whydah at Riverdale Park in Anaheim on 6 September 2014 (Figure 3). Additionally, J. F. Garrett found at least three "families" of Scaly-breasted Munias feeding whydahs at La Mirada Creek Park on 11 August 2014 (Figure 4). Once he learned the juvenile Pin-tailed Whydah's distinctive begging calls (Figure 5), it became evident that fledg- 
ling whydahs were widespread in the residential neighborhood surrounding La Mirada Creek Park. Additionally, he found one group of seven begging juvenile whydahs being fed by a pair of munias at Craig Regional Park on 2 September 2014.

Adult munias often fed mixed broods of juvenile munias and whydahs and of whydahs exclusively. They fed their own young and the whydahs the same material, a regurgitated mash of seeds and vegetative material. Juvenile whydahs were more openly aggressive than their foster sibling munias, begging much more frequently and loudly, following their foster parents more closely, and often positioning themselves between an adult munia and its offspring.

\section{DISCUSSION}

\section{Identification}

Because the native ranges of the Pin-tailed Whydah and Scaly-breasted Munia are allopatric, few references compare the two species. Juvenile Pin-tailed Whydahs are somewhat similar in appearance to juvenile Scalybreasted Munias, so an overview of the criteria distinguishing them is warranted. Juvenile Pin-tailed Whydahs are slightly smaller than a munia, with a shorter tail and a smaller, blunter bill. Young whydahs are overall slightly colder brown than the uniform warm cinnamon-brown of the Scaly-breasted Munia, and their underparts are a much lighter off-white color. Whydahs possess a slightly paler supercilium offset by a dark eyeline not shown by young munias, as well as more contrasting dark lores. Particularly prominent is the gape pattern: young munias show a simple yellow patch, while juvenile whydahs display an elaborate and conspicuous upside-down "U" shape. The begging calls of a juvenile whydah (Figure 5) are distinctly different from those of a juvenile munia (the latter sounding much like the disyllabic "ki-bee" calls of an adult munia).

\section{Other Potential Hosts}

In California the Pin-tailed Whydah could be exploiting brood hosts besides the Scaly-breasted Munia, although its use of any other species is probably limited. The Bronze Mannikin has no known breeding populations in California, but eBird data indicate that numbers of this species are increasing, with up to 25 individuals per day reported at Mile Square Regional Park in Fountain Valley, Orange County. Smaller numbers are found in other localities, such as Huntington Beach and the Whittier Narrows. While J. F. Garrett and others have observed Bronze Mannikins building nests at Mile Square Regional Park, this species constructs communal nest-like roosts (Fry 2004), and actual nesting, though likely, has not been confirmed. The Orange-cheeked Waxbill (Estrilda melpoda) is encountered less frequently than the Bronze Mannikin but also occasionally observed as an escapee in southern California. At Mile Square Park on 12 September 2015, T. Gussler counted and photographed at least 10, including pairs of adults and juveniles (http://ebird.org/ebird/view/ 
checklist?subID=S24997000). Although this species is not known to nest in California, it is a confirmed host of the Pin-tailed Whydah in its native range (Lowther 2016); if it were to nest in California, it seems plausible that the whydah should exploit it.

A less likely additional possible host is the Northern Red Bishop (Euplectes franciscanus) of the weaver family Ploceidae. Its distribution also overlaps substantially with that of the Pin-tailed Whydah in southern California. Whydahs have been observed investigating bishop nests (S. Duncan, pers. comm.), but so far there is no stronger evidence of parasitism.

Although native cardueline fringillids the Lesser Goldfinch (Spinus psaltria), American Goldfinch (S. tristis), and House Finch are also granivores, roughly similar in size to the munia, and frequently nest in the same areas, they are unlikely candidates for parasitism by the whydah, as all build open-cup nests (Hill 1993, Middleton 1993, Watt and Willoughby 1999). All known estrildid hosts of the whydah build domed nests with side entrances (Goodwin 1982). However, Friedmann (1960) cited single apparent instances in Kenya of Pin-tailed Whydah eggs found in the nest of a cardueline finch (Streaky Seedeater, Crithagra striolata) and an emberizid bunting (Golden-breasted Bunting, Emberiza flaviventris). It is worth noting that Scaly-breasted Munias in California breed primarily in late summer and fall, with a smaller peak in late winter and some breeding continuously year round (Smithson 2000; our observations), while native cardueline granivores nest mainly in spring and early summer (Allen et al. 2016). Given the Pin-tailed Whydah's flexibility in host selection, it may be able to select hosts that breed at a season different from the Scaly-breasted Munia's. In Africa breeding by whydahs can occur year -round but is concentrated in rainy periods (Payne 2004).

\section{Other Populations}

The Pin-tailed Whydah has been introduced to several regions away from Africa, including Puerto Rico (Raffaele 1989) and possibly Florida (Greenlaw et al. 2014). While hosts in Florida are unknown, in Puerto Rico the whydah has parasitized the similarly introduced Orange-cheeked Waxbill as hosts (Payne 2010a). Several introduced estrildids, including the Scaly-breasted Munia, have established themselves in Puerto Rico, and it is possible that Pin-tailed Whydahs parasitize them there. Given that at least some California populations of both the Pin-tailed Whydah and Scaly-breasted Munia originated from Puerto Rico rather than through imports directly from Africa and Asia, respectively ( $\mathrm{S}$. Duncan, pers. comm.), the entire relationship between host and parasite may have been transplanted from Puerto Rico to California. Also established in Puerto Rico, however, are other estrildids including the Bronze Mannikin and lesser numbers of the Indian Silverbill (Euodice malabarica), Tricolored Munia (Lonchura malacca), and Java Sparrow (Lonchura oryzivora) (Raffaele 1989, Raffaele et al. 2003; www. eBird.org). Apparent plasticity in selection of a host and the absence of a close correlation between degree of mouthpart mimicry and nestling provisioning and survival in the Pin-tailed Whydah (Schuetz 2005) suggest that 
any of these species could be exploited as a brood host.

\section{Implications of the Munia-Whydah Host-Parasite Relationship}

It is uncertain if the increasing California population of the Pin-tailed Whydah might act as a check on the population of the Scaly-breasted Munias; the latter is considered an actual or potential agricultural pest in its native and introduced ranges (Payne 2010b). Currently the California range of the Pin-tailed Whydah is nested within only about $40 \%$ of the quasi-contiguous range of the Scaly-breasted Munia in southern and central California (www. eBird.org), shadowing the regions with the densest munia populations. A continued expansion of the whydah's range seems likely if the munia is indeed the primary host. We recommend monitoring the whydah's population ecology and behavior as well as the munia and other potential host species that appear to be in the early stages of naturalization in California. Additionally, the troubling, albeit slim, possibility that the Pin-tailed Whydah could parasitize native open-cup nesting granivores such as cardueline finches or emberizid sparrows bears close investigation.

\section{ACKNOWLEDGMENTS}

We are grateful for a research grant from Pasadena Audubon Society to J. F. Garrett to facilitate field work. Many thanks to Jeff Bray for kindly providing his photographs documenting whydah parasitism of munias in Orange County, to Mickey Long for his important sightings, and to Steve Duncan for background on the trade in whydahs and estrildids. Careful reviews by Allison L. Lansverk, Peter Lowther, and Daniel Ruthrauff greatly improved this paper.

\section{LITERATURE CITED}

Allen, L. W., Garrett, K. L., and Wimer, M. C. 2016. Los Angeles County Breeding Bird Atlas. Los Angeles Audubon Soc., Los Angeles, CA.

Friedmann, H. 1960. The parasitic weaverbirds. Bull. U.S.Natl. Mus. 223.

Fry, C. H. 2004. Spermestes cucullata, in in The Birds of Africa (C. H. Fry and S.

Keith, eds.), vol. 7, pp. 401-405. Princeton Univ. Press, Princeton, NJ.

Goodwin, D. 1982. Estrildid Finches of the World. Cornell Univ. Press, Ithaca, NY.

Greenlaw, J. S., Pranty, B., and Bowman, R. 2014. Florida bird species: an annotated list. Fla. Ornithol. Soc. Special Publ. 8.

Hill, G. E. 1993. House Finch (Carpodacus mexicanus) in The Birds of North America (A. Poole and F. Gill, eds.), no. 46. Acad. Nat. Sci., Philadelphia.

Johnston, R. F., and Garrett, K. L. 1994. Population trends of introduced birds in western North America. Studies Avian Biol. 15:221-231.

Lansverk, A. L., Dogmo, J.-B., Schuetz, J. G., and Balakrishnan, C. N. 2015. Parasitism of the Black-crowned Waxbill (Estrilda nonnula) by the Pin-tailed Whydah (Vidua macroura): Implications for host-specific adaptation by a generalist broodparasite. Wilson J. Ornithol. 127:733-739.

Lowther, P. E. 2016. Host list of avian brood parasites - 5 - Passeriformes; Viduidae, version 19 Jan 2016; www.fieldmuseum.org/sites/default/files/ plowther/2016/01/21/vidua-hosts-19jan2016.pdf.

Middleton, A. L. A. 1993. American Goldfinch (Carduelis tristis), in The Birds of North America (A. Poole and F. Gill, eds.), no. 80. Acad. Nat. Sci., Philadelphia.

Mines, B. M. 1999. Hosts of the Pintailed Whydah (Vidua macroura) in southern Africa. Bird Numbers 8:15-21. 
Payne, R. B. 2004. Vidua macroura, in The Birds of Africa (C. H. Fry and S. Keith, eds.), vol. 7, pp. 420-423. Princeton Univ. Press, Princeton, NJ.

Payne, R. B. 2010a. Family Viduidae (whydahs and indigobirds), in Handbook of the Birds of the World (J. del Hoyo, A. Elliott, and D. A. Christie, eds), vol. 15, pp. 198-232. Lynx Edicions, Barcelona.

Payne, R. B. 2010b. Family Estrildidae (waxbills), in Handbook of the Birds of the World (J. del Hoyo, J., A. Elliott, and D. A. Christie, eds.), vol. 15, pp. 234-377. Lynx Edicions, Barcelona.

Pike, J. E., Garrett, K. L., and Searcy, A. J. 2014. The 38 $8^{\text {th }}$ annual report of the California Bird Records Committee: 2012 records. W. Birds 45:246-275.

Pranty, B., and Garrett, K. L. 2011. Under the radar: Non-countable exotic birds in the ABA area. Birding 43:46-58.

Raffaele, H. A. 1989. A Guide to the Birds of Puerto Rico and the Virgin Islands. Princeton Univ. Press, Princeton, NJ.

Raffaele, H., Wiley, J., Garrido, O., Keith, A., and Raffaele, J. 2003. Birds of the West Indies. Princeton Univ. Press, Princeton, NJ.

Schuetz, J. 2005. Low survival of parasite chicks may result from their imperfect adaptation to hosts rather than expression of defenses against parasitism. Evolution 59:2017-2024.

Smithson, W. S. 2000. Breeding biology of the Orange Bishop (Euplectes franciscanus) and Nutmeg Mannikin (Lonchura punctulata) in southern California. Master's thesis, Calif. State Univ., Long Beach.

Watt, D. J., and Willoughby, E. J. 1999. Lesser Goldfinch (Carduelis psaltria), in The Birds of North America (A. Poole and F. Gill, eds.), no. 392. Birds N. Am., Philadelphia.

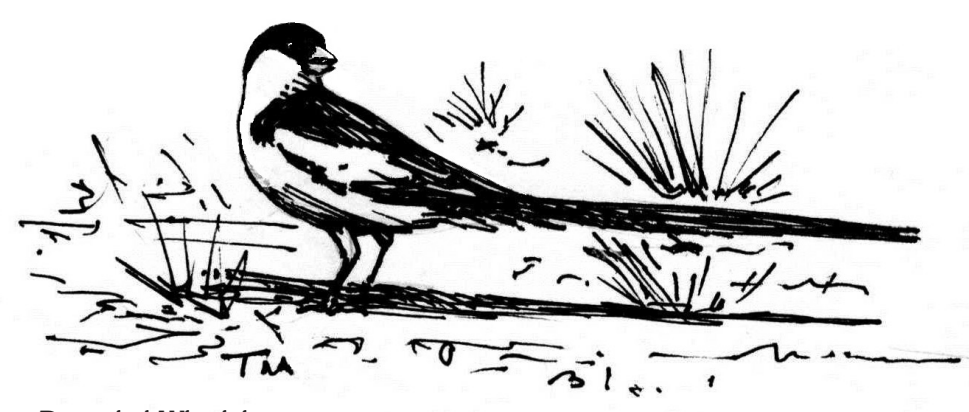

Pin-tailed Whydah 